ПСИХОлогИя

DOI: $10.17805 /$ trudy.2017.2.1

\title{
ГЛОБАЛИЗАЦИЯ КАК ФАКТОР ВЛИЯНИЯ НА ФОРМИРОВАНИЕ СЕМЬИ И СЕМЕЙНЫХ ЦЕННОСТЕЙ В СОВРЕМЕННОЙ РОССИИ
}

\author{
А. Р. Субочева, Н. В. Каргина \\ Московский гуманитарный университет
}

Аннотация: В статье рассматривается процесс глобализации как фактор влияния на формирование современной российской семьи и девальвации семейных цзенностей у современной молодежи.

Ключевые слова: правовые ценности; культурные ценности; западная культура; азиатская культура; мусульманская культура; процесс регионализации

\section{GLOBALIZATION AS AN INFLUENCE FACTOR FOR FAMILY AND FAMILY VALUES FORMATION IN MODERN RUSSIA}

\author{
A. R. Subocheva, N. V. Kargina
}

Abstract: The article examines globalization mechanisms as influence factors for the formation of the modern Russian family and the devaluation of family values among modern young people.

Keywords: family; family values; globalization; demographic crisis; migration

Чаще всего глобализацию, как фактор влияния на жизнь людей, рассматривают в экономическом или социальном ключе. Однако никто не будет отрицать тот факт, что глобализация оказывает огромное влияние на частную жизнь людей, в том числе и на формирование семейных ценностей. Каким же образом реализуется это влияние?

Прежде всего необходимо определиться с самим понятием «глобализация». Мы слышим это слово до сотни раз в день с экранов телевидения, в программах на радио, читаем в новостных лентах в интернете, понятие активно обсуждается в социальном и гуманитарном знании (см.: 
Журавлев, 2004; Федотова, 2004a, 2005ab; Хорина, 2005; Межуев, 2009: Электр. ресурс и др.). Глобализация, в основном, представляется учеными как процесс всемирной политической, экономической, религиозной и культурной унификации и интеграции. Один из огромнейших плюсов процесса глобализации - любая информация, благодаря Интернету теперь доступна всем в любое время дня и ночи. Любая библиотека мира теперь в каждом доме, стоит только захотеть. К положительному влиянию можно отнести экономические плюсы, такие как трудовая миграция, облегчение хозяйственных взаимодействий между странами, возможность экономить ресурсы, разделять производство и многое другое. Однако помимо плюсов, существует и ряд минусов, с которыми приходится считаться. Одним из огромных минусов глобализации, на наш взгляд, является отрицательное влияние на региональные культурные ценности, в частности на ценности семьи и материнства (Дементьева, 2013; Гурко, 2008; Пещеров, Пирогов, 2013 и др.).

Прежде всего необходимо отметить тот факт, что в условиях глобальной экономики неизбежным становится постоянный процесс миграции людей в более благополучные страны и чаще всего речь идет не о законной трудовой миграции, когда люди заключают контракты и переезжают, а о нелегальной иммиграции. Люди, таким образом приехавшие в страну часто оказываются бесправными, помимо экономической опасности, они попадают в позицию дискриминируемых местным населением, что может стать причиной конфликтов. В нашей стране эта проблема стоит достаточно остро. Даже федеральные службы не могут дать точный ответ на вопрос, сколько в Москве мигрантов. Официально за январь-февраль 2017 г. в Москву приехало и встало на учет 1606230 иностранных граждан и лиц без гражданства (Сведения о миграционной ситуации ..., 2017: Электр. ресурс). Сколько их на самом деле, не знает никто. Все это оказывает негативное влияние на психологическое состояние граждан - растет тревожность населения, большое число мигрантов отрицательно влияет на рынок труда, что в свою очередь ограничивает стремление молодежи вступать в брак.

Говоря о миграции как элементе глобализации необходимо отметить факт разрывания семейных связей из-за смены места жительства. Даже если люди мигрируют семьями, они оказываются оторваны от своего привычного окружения, лишаются поддержки родственников и друзей и попадают в ситуацию перманентного стресса, что приводит к психологическим проблемам у всех членов семьи.

Ни для кого не секрет, что в России сейчас период демографического кризиса (Ильинский, 2010). Молодежь не торопится вступать в брак, это связано в том числе с состоянием неуверенности в завтрашнем дне, боязнь оказаться невостребованным в условиях глобализации. Поскольку 
в России традиционной является именно патриархальный уклад семьи, где мужчина играет роль «добытчика», а женщина «хранительницы очага», то увеличивается возраст вступления в брак у мужчин, так как они часто оказываются не готовы брать на себя долгосрочные обязательства и нести ответственность не только за себя, но и за свое потомство. Для женщин эта ситуация также является достаточно стрессовой, так как часто им приходится уходить от традиционной роли и принимать на себя «мужские» обязательства.

Сегодня женщины часто работают наравне с мужчинами, рано выходят из декретного отпуска и в итоге рождают не более одного ребенка. Для значительной части женщин стремление построить карьеру и обеспечить свою материальную независимость приводит не только к ролевому конфликту и сложностям в построении отношений, но и к неспособности завести детей в силу биологических особенностей женского организма. Однако глобализация помогает «решить» и эту, казалось бы, нерешаемую проблему с помощью суррогатного материнства, когда женщину фактически покупают, как инкубатор для чужого потомства. Понятно, что это нельзя назвать здоровым семейным взаимодействием.

Еще одним из важных аспектов влияния глобализации на семью является все большее распространение межнациональных браков. Такие семьи сталкиваются с большим количеством проблем, таких как конфликты, вызванные разницей норм супружеского поведения, воспитания детей и религиозным фактором.

В России семья и семейные ценности в настоящее время находятся в глубоком кризисе (см. напр.: Вишневский, 2008; Субочева, Каргина, 2017: Электр. ресурс). Это происходит, на наш взгляд, как раз из-за внедрения в сознание людей ценностей, которые являются чуждыми традиционной российской семье. Осуществляется это именно благодаря глобализации, которая привносит в традиционно патриархальное общество тенденции индивидуализма, излишнюю эмансипацию, которая приводит к изменению гендерных ролей, толерантность к нетрадиционным формам семьи. Вслед за странами Запада российская семья «стареет», становится малодетной. Увеличивается число нерегистрируемых союзов и распространяется добровольная бездетность «чайлд фри».

Сегодня не только правительство всерьез обеспокоено проблемой обесценивания российской семьи и снижением семейных ценностей для современной молодежи. Проводятся различные инициативы, которые возможно поспособствуют усилению позиций семьи в современном российском обществе. По мнению Т. А. Гурко, специфика России состоит в том, что уже в индустриальный период прошлого века российские женщины работали вне дома. Поэтому вхождение нового поколения российских женщин (воспитанных на примере своих матерей) в постиндустри- 
альное общество, возможно, будет происходить с меньшими издержками в плане сочетания профессиональных, супружеских и родительских ролей (Гурко, 2008). Все это внушает некоторый оптимизм и оставляет надежду, что российская семья все же сможет сохранить свое традиционное лицо. А это очень важно, ведь именно семья является основой стабильно развивающегося общества, а семейные ценности выступают необходимым базисом для психологического здоровья современной молодежи. Поэтому необходимо, как осмысление проблем современной семьи, так и ее всестороння поддержка.

\section{СПИСОК ЛИТЕРАТУРЫ}

Вишневский, А. Г. (2008) Эволюция российской семьи. Кризис семейных ценностей с исторической точки зрения // Экология и жизнь. № 7. C.4-11.

Гурко, Т. А. (2008) Трансформация института родительства в постсоветской России : дисс. ... д-ра соц. н. М. 342 с.

Дементьева, И. Ф. (2013) Изменение института семьи в условиях глобализации // Социальная педагогика. № 6. С. 5-12.

Журавлев, В. В. (2004) Глобализация: вызовы истории и ответы теории // Знание. Понимание. Умение. № 1. С. 43-46.

Ильинский, И. М. (2010) О ситуации, некоторых прогнозах и стратегиях развития негосударственного высшего профессионального образования в России в связи с демографической ямой // Знание. Понимание. Умение. № 4. С. 4-15.

Межуев, В. М. (2009) Ценности современности в контексте модернизации и глобализации [Электронный ресурс] // Информационногуманитарный портал «Знание. Понимание. Умение». № 1. URL: http:// www.zpu-journal.ru/e-zpu/2009/1/Mezhuev/ (дата обращения: 12.01.2017).

Пещеров, Г. И., Пирогов, А. И. (2013) Институт семьи: эволюция и проблемы в современном мире // Власть. № 10. С. 106-109.

Сведения о миграционной ситуации в Российской Федерации (2017) [Электронный ресурс] // Министерство внутренних дел Российской Федерации. URL: https://xn--b1aew.xn--p1ai/upload/site1/document_ news/009/677/570/Dlya_sayta_1702_PDF.pdf (дата обращения: 11.03.2017).

Субочева, А. Р., Каргина, Н. В. (2017) Проблемы современного ценностного отношения к материнству в России [Электронный ресурс] // Научные труды Московского гуманитарного университета. № 1. URL: http:// journals.mosgu.ru/trudy/article/view/396 (дата обращения: 12.04.2017). DOI: $10.17805 /$ trudy.2017.1.5

Федотова, В. Г. (2004а) Меняющийся мир и глобализация (начало) // Знание. Понимание. Умение. № 1. С. 47-59. 
Федотова, В. Г. (2005а) Меняющийся мир и глобализация (продолжение) // Знание. Понимание. Умение. № 1. С. 44-55.

Федотова, В. Г. (2005b) Меняющийся мир и глобализация (окончание) // Знание. Понимание. Умение. № 2. С. 94-104.

Хорина, Г. П. (2005) Глобализация как идеология // Знание. Понимание. Умение. № 1. С. 71-78.

Дата поступления: 15.04.2017 г.

Субочева Алина Романовна - магистрант по специальности психология Московского гуманитарного университета. Адрес: 111395, Россия, г. Москва, ул. Юности, д. 5. Тел.: +7 (499) 374-67-20. Эл. адрес: subocheva@ bk.ru. Научный руководитель - к. псих. н., доц. Н. В. Каргина.

Каргина Наталья Вячеславовна - кандидат психологических наук, доцент, доцент кафедры общей психологии и истории психологии Московского гуманитарного университета. Адрес: 111395, Россия, г. Москва, ул. Юности, д. 5. Тел.: +7 (499) 374-67-20. Эл. адрес: kanat99@ya.ru

Subocheva Alina Romanovna, Graduate Student, Department of General Psychology and History of Psychology, Moscow University for the Humanities. Postal address: 5, Yunosti St., Moscow, Russian Federation 111395. Tel.: +7 (499) 374-67-20. E-mail: subocheva@bk.ru. Scientific Adviser - N. V. Kargina, Candidate of Psychology, Associate Professor.

Kargina Natalia Vyacheslavovna, Candidate of Psychology, Associate Professor, Department of General Psychology and History of Psychology, Moscow University for the Humanities. Postal address: 5, Yunosti St., Moscow, Russian Federation 111395. Tel.: +7 (499) 374-67-20. E-mail: kanat99@ya.ru

\section{Для циитирования:}

Субочева А. Р., Каргина Н. В. Глобализация как фактор влияния на формирование семьи и семейных ценностей в современной России [Электронный ресурс] // Научные труды Московского гуманитарного университета. 2017, № 2. URL: http:// journals.mosgu.ru/trudy/article/view/447 (дата обращения: дд.мм.гг.). DOI: 10.17805/ trudy.2017.2.1 